\title{
A IMPORTÂNCIA DAS BOAS PRÁTICAS DE ORDENHA NA PRODUÇÃO DE LEITE CRU REFRIGERADO
}

\section{ARTIGO DE REVISÃO}

CAPPELLI, Sandro ${ }^{1}$

BOFF, Izamara ${ }^{2}$

BONFANTE, Cheilane ${ }^{3}$

CAVAGNI, Daniel ${ }^{4}$

LEID, Luana Karine ${ }^{5}$

CAPPELLI, Sandro. Et al. A importância das boas práticas de ordenha na produção de leite cru refrigerado. Revista Científica Multidisciplinar Núcleo do Conhecimento. Ano 04, Ed. 07, Vol. 13, pp. 79-102. Julho de 2019. ISSN: 2448-0959

\section{RESUMO}

O Brasil é uma nação de grande importância no setor de produção de leite, tudo devido às grandes extensões de terras que facilitam a criação do gado de leite, como também o clima que favorece a exploração na bovinocultura. Além de ser um grande produtor,

\footnotetext{
${ }^{1}$ Especialista em Gestão da Segurança de Alimentos - Senac SP; Zootecnista - IFRS.

2 Engenheira de Alimentos formadas pela Fundação Universidade de Passo Fundo UPF Campus Passo Fundo.

${ }^{3}$ Engenheira de Alimentos formadas pela Fundação Universidade de Passo Fundo UPF Campus Passo Fundo.

${ }^{4}$ Biólogo formado pela Fundação Universidade de Passo Fundo - UPF Campus Passo Fundo.

${ }^{5}$ Acadêmica do curso de Engenharia de Produção do Centro Universitário João Paulo II - Campus Passo Fundo.
} 
- Brasil também é um grade consumidor, consumindo em torno de 170 litros/habitante/ano. Com o crescimento da exploração da produção e do consumo, o mercado teve que tomar algumas providências para garantir a qualidade higiênicosanitária do produto, tudo devido ao fato de que o leite cru prover de diversos sistemas de produção em diferentes localidades e de muitas formas de manejo. Para assegurar a qualidade do produto, o Ministério da Agricultura Pecuária e Abastecimento criou as boas práticas de ordenha que se enquadram na Instrução Normativa 62 de 29 de Dezembro de 2011, que tem por finalidade criar um padrão de manejo e higiene na exploração do leite, assim como também determina parâmetros de qualidade através de características químicas, físicas e biológicas. As boas práticas tem a grande finalidade de aumentar a qualidade do leite e derivados e diminuir o prejuízo pelas indústrias beneficiadoras, já que vários estudos comprovam a perda de qualidade, rendimento e características dos subprodutos produzidos com leite fora dos padrões de qualidade

Palavras-chave: qualidade, ordenha, manejo, higiene.

\section{INTRODUÇÃO}

A Importância da produção de leite no Brasil é algo incontestável. Segundo o IBGE (2015) a produção de leite no Brasil no ano de 2014 foi de aproximadamente 24,7 bilhões de litros, gerando um valor bruto de produção de aproximadamente 15 bilhões de reais.

Não é somente a produção que é relevante no nosso país, o consumo de leite e derivados e a exportação de ambos também é acentuada. De acordo com ZOCCAL (2016) além do Brasil estar no quarto lugar no ranking de produção mundial também é um grande consumidor, com um consumo de 170 litros/habitante/ano.

Uma boa parcela da economia brasileira também é movimentada pelo mercado do leite. Os empregos gerados vão de pequenas até grandes cidades, estando presente em $99 \%$ dos municípios do Brasil, gerando renda fixa a milhares de famílias que dependem da exploração do comodite no meio rural (ZOCCAL, 2016). 
Com o crescimento da demanda e da produção, foram também aumentados os controles e requisitos para produção de leite cru com qualidade, principalmente no que se diz respeito ao processo de produção no campo. Desta forma a produção de leite, passou a necessitar de uma forma de manejo que diminuísse a contaminação microbiana, aumentando a segurança e a qualidade do produto (OLIVEIRA, 2015).

Com o passar do tempo e os diversos estudos realizados relacionando a qualidade com a produção, conseguiu-se obter diversos resultados de perda na qualidade e rendimento na produção de derivados, e a diminuição do tempo de prateleira. Devido a estes quesitos as empresas beneficiadoras começaram a pagar o produtor não apenas pela quantidade, mas também pela qualidade do produto.

Com o intuito de aumentar a qualidade do leite produzido e dos seus derivados o MAPA criou algumas práticas de manejo que tem por finalidade diminuir a contaminação e aumentar a qualidade do produto (OLIVEIRA, 2015). A partir disso, os programas de qualidade tomaram outra forma e as boas práticas agropecuárias na produção de leite foram implementadas, com a principal finalidade de garantir um produto com boa qualidade higiênico-sanitária.

\subsection{OBJETIVO}

Realizar uma revisão bibliográfica enfatizando o manejo e os parâmetros que ocasionam a diminuição da qualidade do leite cru refrigerado.

\subsubsection{OBJETIVOS ESPECÍFICOS}

Diferenciar os tipos de ordenha que existem enfatizando os manejos adequados em cada sistema.

Descrever quais sãos os parâmetros de qualidade do leite que podem acarretar em perda no valor do produto á campo ou descarte do mesmo.

Demonstrar a importância das boas práticas na produção de leite em propriedades rurais. 
Apresentar os principais parâmetros e objetivos da IN № 62, de 29 de Dezembro de 2011, que dispõe da identidade e qualidade do leite cru.

\section{DESENVOLVIMENTO}

\subsection{SITUAÇÃO DO MERCADO DO LEITE NO BRASIL}

A produção de leite no Brasil cresceu de uma forma relativamente constante desde 1974 até os dias atuais, segundo dados do IBGE (2011) o Brasil saiu do patamar de 7,1 bilhões de litros de leite para 32,1 bilhões de litros em 2011.

O crescimento da produção de leite no Brasil tem duas vertentes. O primeiro diz respeito ao aumento do número de vacas ordenhadas, com isso o consequente aumento da capacidade produtiva. O segundo deve-se ao crescimento da produtividade dos animais brasileiros, decorrente de nutrição e melhoramento genético animal (MAIA et al, 2010).

Através de dados do IBGE (2011) pode-se destacar que o manejo, melhoramento genético e tecnologias voltadas à nutrição do gado de leite formam os maiores influenciadores para a produtividade atual. Em 1974 uma vaca produzia em uma lactação aproximadamente 655 litros de leite, em 2011 a média aumentou para aproximadamente 1.381 litros.

A produção nacional de leite em 2015 foi de 34 bilhões de litros, colocando país como a quarta nação com maior produção de leite no mundo. São em torno de 1,3 milhões de propriedades que produzem leite, existindo uma predominância de $99 \%$ dos municípios produzindo, com um rebanho de 23 milhões de vacas ordenhadas (ZOCCAL, 2016).

Existem cerca de 2 mil indústrias beneficiadoras e processadoras inspecionadas pelo Serviço de Fiscalização Federal (SIF). Movimentando a economia de pequenas e grandes cidades com a média de consumo de 170 litros/leite/habitante/ano (ZOCCAL, 2016). 
O consumo de leite por habitantes ainda é pequeno quando comparado com países desenvolvidos, cujo poder aquisitivo da população é mais elevada. A média de consumo nestes países alcança 220 litros/leite/habitante/ano. Para conseguir atender o crescimento populacional, o Brasil deverá sair da produção atual de 37 bilhões de litros anuais para 48 bilhões em 2026 (ZOCCAL, 2016).

Para conseguir atender o crescimento populacional deverá haver um aumento expressivo na produção de leite no Brasil. Além do aumento do número de animais, o crescimento da tecnologia na produção de leite deverá ser de grande relevância.

As propriedades que produzem leite de maneira simples deverão tecnificar a produção de leite, através de animais com maior potencial genético, investir profundamente em nutrição e migrar da forma manual de ordenha para sistemas mecanizados e canalizados, que além de minimizar a mão de obra tem a finalidade de proporcionar um aumento da qualidade do leite.

\subsection{TIPOS DE ORDENHA}

A ordenha se define pelo ato de realizar a extração do leite contido na glândula mamária, podendo ser feito de forma manual ou de forma mecânica. É uma prática que deve ser realizada com muito cuidado, pois dependendo das condições de execução pode influenciar na quantidade e qualidade do produto (NETTO et al 2006).

De acordo com NETTO et al (2006) os cuidados no manejo de ordenha são muito importantes, pois ocorre todo o resultado da produção leiteira. Segundo o mesmo autor os benefícios econômicos de uma boa ordenha proporcionarão os seguintes ganhos:

- Aumento da produção, pois vacas sadias produzem mais.

- Melhor qualidade do leite, ou seja, ausência de condenação do leite na plataforma dos laticínios.

- Menores gastos com medicamentos, mão-de-obra e assistência veterinária e zootécnica. 
- Ausência de quartos perdidos, considerados como fonte de contaminação e também fêmeas descartadas em face das mamites ocorridas no rebanho.

Independente da forma da ordenha e da tecnologia empregada para a execução deste manejo, o profissional responsável pela ordenha é considerado o elo mais importante no processo, somente ele poderá manter uma ordenha higiênica, silenciosa, tranquila e rápida (NETTO et al 2006).

\subsubsection{ORDENHA MANUAL}

A ordenha manual é o método mais antigo de extração de leite, mas ainda é utilizado em diversas propriedades rurais no Brasil, principalmente em locais que o leite entra como um produto de subsistência (CARVALHO et al, 2013).

$\mathrm{Na}$ ordenha manual o leite é tirado pelas mãos do ordenhador em um balde. Os utensílios principais utilizados nesta modalidade de ordenha são: balde, coador/filtro para transferir o leite do balde para o tanque de refrigeração, a peia para conter as pernas das vacas e um banquinho para o ordenhador se sentar e realizar o procedimento (EMBRAPA, 2008).

A Figura 1 representa de forma clara o método de ordenha realizada na forma manual, onde o ordenhador utiliza as mãos para conseguir realizar a ejeção do leite das glândulas mamárias para o balde de coleta. Lembrando sempre que após cada balde ordenhado o leite deve ser transferido para um sistema de refrigeração. 
Figura 1. Sistema de ordenha manual.

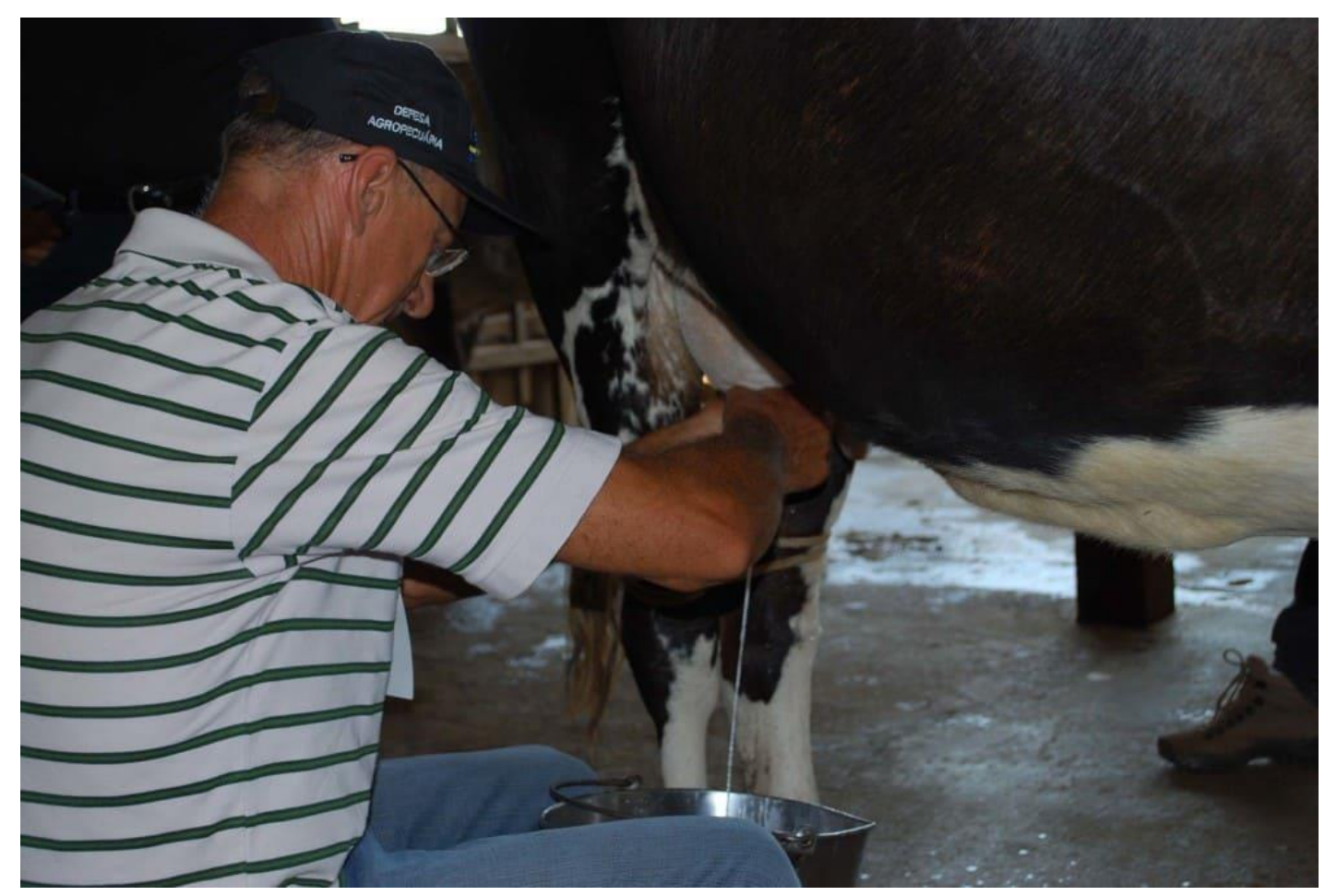

Fonte: MARTINS (2012).

\subsubsection{ORDENHA MECANIZADA}

A ordenha mecânica é realizada através de um equipamento de vácuo chamado ordenhadeira. Este equipamento simula a mamada de um bezerro, que através da pressão e sucção faz a ejeção do leite (EMBRAPA, 2008).

Este sistema de ordenha pode ser dividido em dois tipos: a ordenha mecânica balde ao pé e a ordenha mecânica canalizada.

A Figura 2 representa a ordenha balde ao pé. Neste tipo de ordenha mecanizada o leite é retirado por uma ordenhadeira então é encaminhado para um taro de leite que fica móvel junto com o animal, quando o taro encontra-se cheio, o conteúdo é despejado dentro de um resfriador. 
Figura 2. Sistema de ordenha mecânica do tipo balde ao pé.

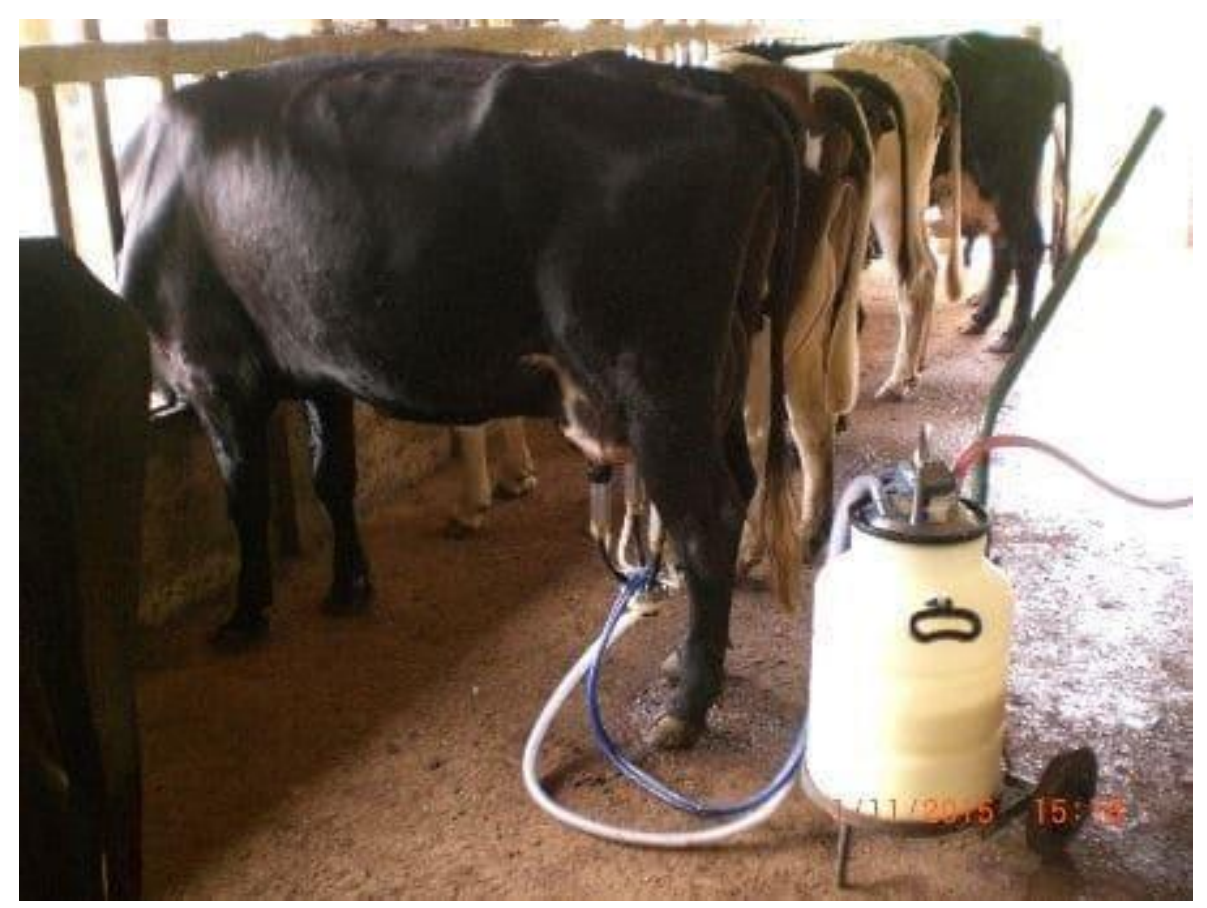

Fonte: JUNIOR (2015).

A Figura 3 representa um sistema de ordenha mecânico canalizado. A grande diferença para o sistema de balde ao pé é o de que conforme o leite é ordenhado, ao invés de ser encaminhado para um taro móvel de recolhimento, o leite é direcionado de forma canalizada para o sistema de resfriamento, diminuindo a mão de obra e facilitando o trabalho. 
Figura 3. Sistema de ordenha mecânica canalizada.

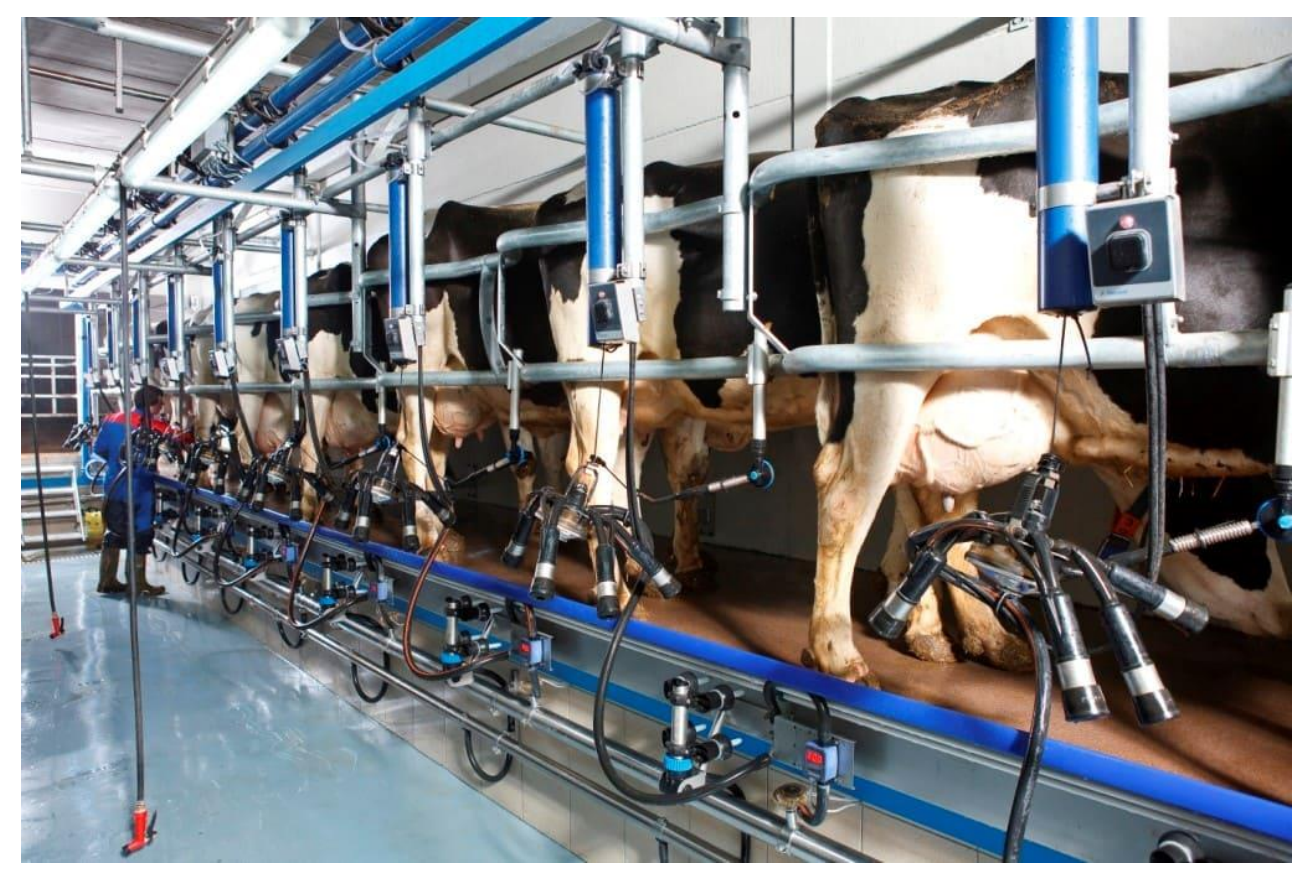

Fonte: DELAVAL (2015).

A Figura 4 representa um sistema de ordenha mecânica canalizada do tipo carrossel. Neste sistema através de um plataforma giratória os animais entram no carrossel, são realizados os manejos de limpeza e ordenha com o carrossel girando e após o término do manejo os animais saem do sistema giratório.

Figura 4. Ordenha mecânica canalizada do tipo carrossel.

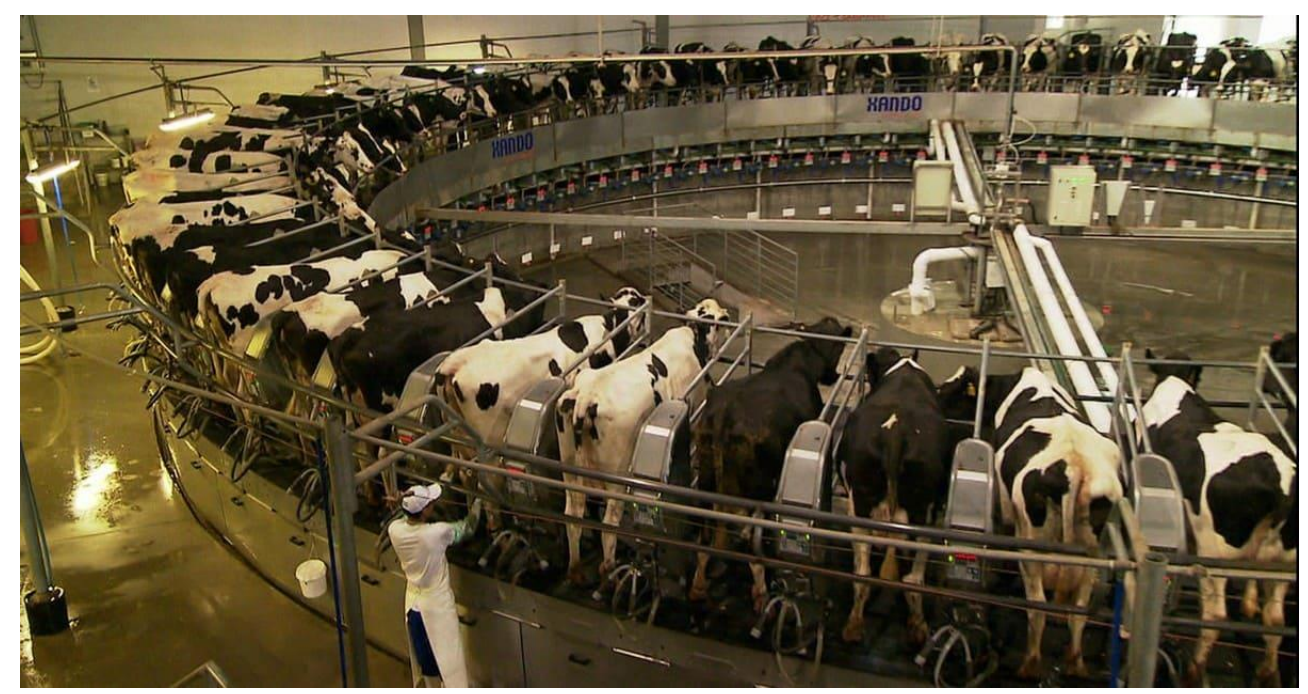

$\mathrm{RC}: 34853$

Disponível em: https://www.nucleodoconhecimento.com.br/zootecnia/producao-de-leite 
Fonte: GLOBO RURAL (2015).

A Figura 5 representa um sistema de ordenha canalizada robotizada. Neste sistema de ordenha não necessita de ordenadores, a máquina faz tudo sozinha. Quando o animal se aproxima do sistema de ordenha é identificado por um chip, o qual abre a porta do sistema e ela mesma direciona-se para a coleta, desta forma o próprio equipamento faz a limpeza e o encaixe das teteiras diretamente nos tetos do úbere.

Figura 5. Sistema de ordenha canalizada robotizada.

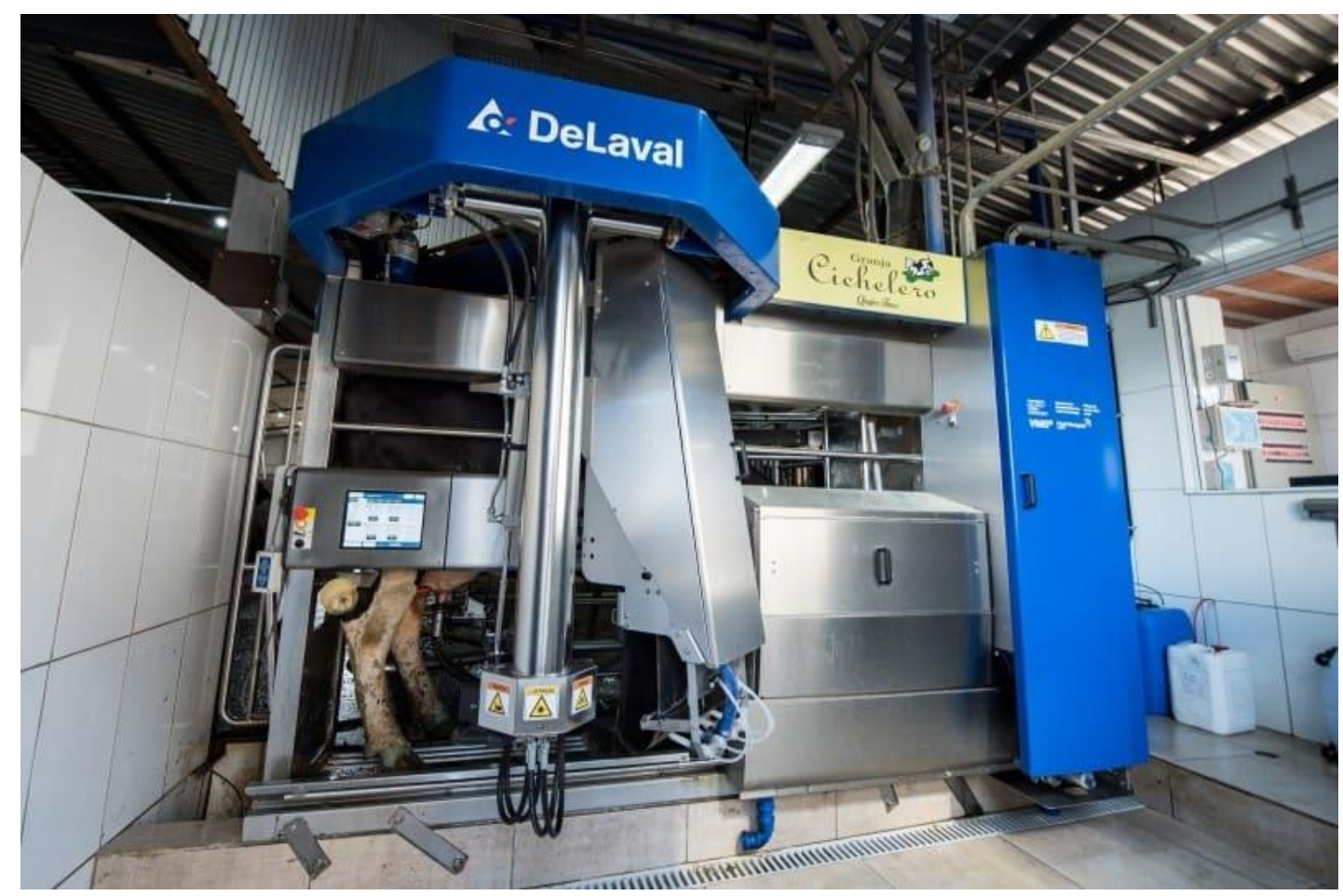

Fonte: CICHERELO (2017).

\subsection{MANEJO DE BOAS PRÁTICAS PRÉ-ORDENHA}

A experiência e competência do profissional de ordenha são de extrema importância para o sucesso dos procedimentos. $\mathrm{O}$ ordenhador deve manter uma rotina rigorosa e com horários que devem ser seguidos à risca, pois os animais acostumam-se com o sistema de ordenha adotado, e qualquer mudança pode gerar problemas no processo. 
Segundo LANGONI et al (2011) o controle de qualidade no setor de laticínios iniciase muito antes mesmo da ejeção da matéria prima, pois o leite de qualidade somente é obtido de animais sadios, adequadamente manejados, bem nutridos e livres de doenças e infecções.

Segundo ROSA et al (2009) ao elaborar o Manual de Boas Práticas de Manejo de ordenha, o mesmo descreve que deve ser seguida uma fila de ordenha que segue de acordo com a situação e o histórico de cada animal, com o intuito de manter a sanidade de todo o rebanho. A ordem de ordenha deve ser seguida da seguinte forma:

- Vacas primíparas, de primeira cria e que nunca tiveram problemas de mastite;

- Vacas pluríparas que nunca tiveram problema de mastite;

- Vacas que já tiveram mastite, mas que já foram tratadas e curadas;

- Vacas com Mastite subclínica (leite descartado);

- Vacas com mastite clínica (leite descartado);

- Vacas com tratamento com antibiótico (leite descartado).

Antes mesmo de iniciar o processo de ordenha devem ser lavados todos os equipamentos que serão utilizados, pois a contaminação por microrganismos ocorre principalmente por causa da sujeira e da falta de cuidado no pré-ordenha (BELOTI et al, 2008). A falta de higiene e cuidados na ordenha pode gerar um aumento na Contagem Bacteriana Total no leite (CBT) diminuindo a qualidade do produto refrigerado (ECKSTEIN et al, 2014).

De acordo com BRITO et al (2002) a contagem bacteriana total (CBT) e a Contagem de células somáticas do leite (CCS) e a presença de algum resíduo de antibiótico determina a qualidade higiênica e sanitária do leite, e as práticas de manejo de limpeza são as mais importantes para a obtenção de um leite de qualidade.

Para diminuir a CBT no leite, os baldes, latões, e todo o sistema de ordenha fechado deve passar por uma lavagem com detergente alcalino clorado, dissolvido e com tempo de ação conforme indica a embalagem de cada produto para limpeza de 
ordenha, registrado pelo Ministério da Agricultura Pecuária e Abastecimento (BELOTI et al, 2008).

Após deixar o detergente agir pelo tempo indicado na embalagem, os utensílios e o sistema de ordenha devem ser enxaguados, até que saia todo o detergente contido, não deixando resíduos do produto (BELOTI et al, 2008).

Já com a sala e equipamentos limpos os animais devem ser conduzidos para a sala de ordenha. A condução deve ser realizada de uma forma calma, de vagar e sem gritos, sem o uso de qualquer instrumento de agressão, evitando qualquer tipo de estresse ao animal (MARASSATTO, 2014).

Deixar o animal estressado pode ocasionar a não liberação de todo o leite contido no úbere, chamado de leite alveolar. $\mathrm{O}$ acumulo de leite residual no úbere pode ocasionar problemas de mastite. A mastite faz com que aumente a quantidade de células somáticas no leite (CCS), diminuindo a qualidade do produto (MARASSATTO, 2014).

\subsection{MANEJO DE BOAS PRÁTICAS NA ORDENHA}

O ordenhador é chave principal deste processo, o mesmo deve realizar a ordenha sempre com um bom aspecto de higiene pessoal. As mãos sempre deverem estar bem limpas, unhas e barbas aparadas, possivelmente utilizar um avental na ordenha e luvas descartáveis nas mãos (ZAFALON et al, 2008).

Quando os tetos dos animais apresentam-se sujos deve-se realizar a lavagem dos tetos com água limpa e corrente, sem molhar a região do úbere, para que não ocorra a decida de água contaminada para o interior das teteiras (ZAFALON et al, 2008).

Após a lavagem dos tetos, deve-se retirar os três primeiros jatos de leite em uma caneca de fundo preto. Estes três primeiros jatos tem o intuito de limpar o canal do leite e de diagnosticar mastite clínica. Quando o leite apresentar grumos na caneca preta é sinal de que a vaca está com problema de mastite, que quando diagnosticado o leite não deve ser utilizado e o animal deve passar por um tratamento com antibióticos (ZAFALON et al, 2008). 
A figura 6 está relacionada a um teste de fundo de caneca preta com os três primeiros jatos de leite aonde é diagnosticada mastite clínica. Além da mastite clínica, uma vez por semana deve-se realizar em todos os animais do rebanho um teste de CMT (California mastitis test) que é utilizado para diagnosticar mastite subclínica. Quando diagnosticado este tipo de mastite, o leite também deve ser descartado e o animal deve ser encaminhado para tratamento com antibióticos.

Figura 6. Diagnóstico de mastite clínica.

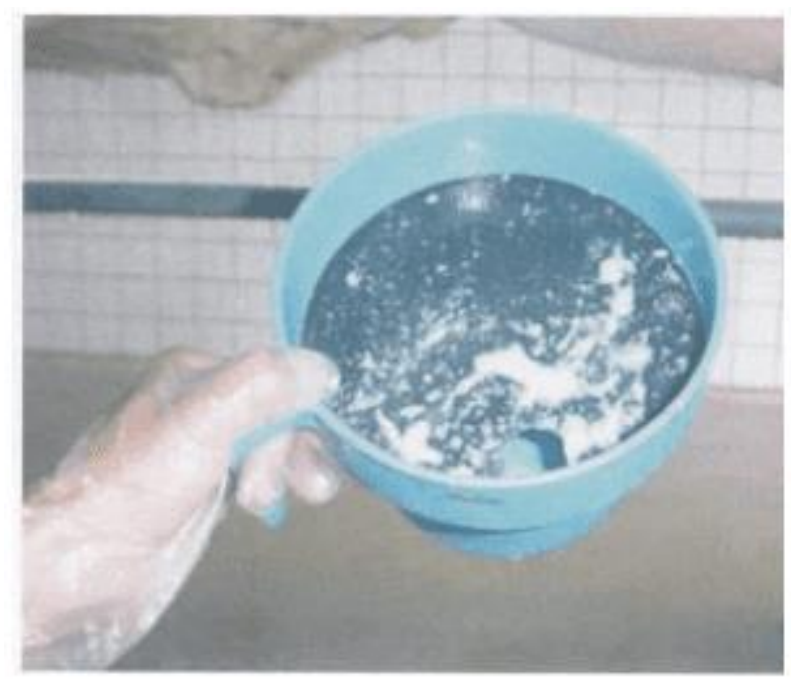

Fonte: SENAR (2004).

\section{A Figura 7}

representa um teste de CMT com resultado normal e a Figura 8 representa um teste de CMT com uma vaca acometida por mastite subclínica apresentando uma formação gelatinosa do leite com o reagente.

Segundo ZAFALON et al (2008) este teste é composto por um detergente e um indicador de $\mathrm{pH}$. Este reagente atua sobre os leucócitos e outras células presentes no leite que são liberadas quando existe um processo inflamatório na glândula mamária. Este detergente causa um rompimento da parede destas células, liberando o material genético, promovendo a formação de uma viscosidade. 
Figura 7. Teste de CMT com resultado normal.

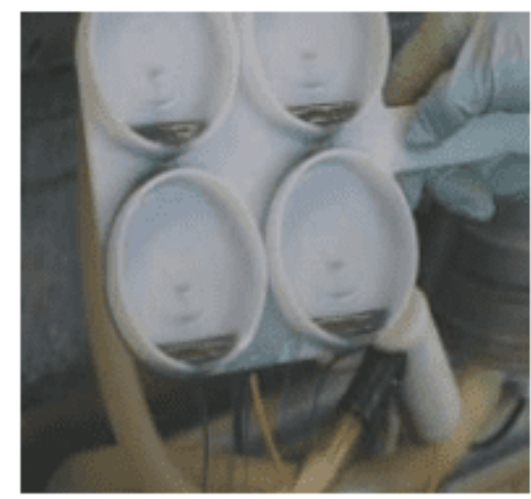

Fonte: SENAR (2004).

Figura 8. Teste de CMT com resultado positivo para mastite subclínica.

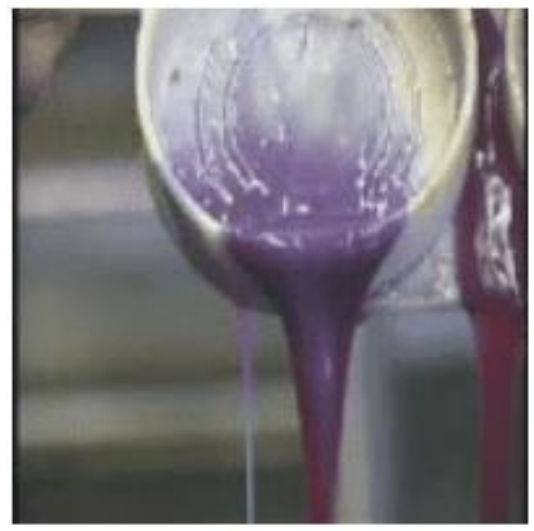

Fonte: SENAR (2004).

Após a lavagem dos tetos quando apresentarem sujidades e a realização dos testes de mastite em todos os tetos e ambos apresentarem resultado negativo deve-se realizar o pré-dipping nos animais.

O pré-dipping é um processo de assepsia dos tetos que consiste em mergulhar todos os tetos em uma solução a base de iodo, clorexidina ou cloro (SANTOS \& FONSECA, 2007). 
Segundo SILVA et al (2002) as concentrações do produtos devem ser da seguinte forma: $2 \%$ quando for a base de hipoclorito de sódio, 0,3\% para iodo e $0,3 \%$ para clorexidina.

A assepsia quando bem realizada tem a capacidade de reduzir em até $50 \%$ a taxa de novas infecções causadas por patógenos ambientais e diminui a contaminação dos tetos antes da ordenha (MORINI, 2009).

Deixa-se o produto agir nos tetos por 60 segundos e após isso pé realizada a secagem do produto nos tetos. Secar o produto é de grande importância, pois evita que o antisséptico entre no sistema de ordenha e evita o deslizamento das teteiras devido à viscosidade do produto (MORINI, 2009). Segundo SANTOS \& FONSECA (2007) os tetos devem ser secados com papel toalha individual para cada teto, desta forma diminui a contaminação de um animal para o outro e entre os tetos.

Quando a ordenha é realizada na forma manual o ordenhador deve estar com as mãos limpas ou utilizar luvas para realizar o manejo. É importante sempre verificar que todo o úbere tenha sido esgotado, pois o leite residual pode causar problemas de inflamação na glândula mamária (ROSA et al, 2009).

Quando o procedimento é realizado com ordenhadeira mecânica deve-se manter o vácuo fechado até o momento do encaixe das teteiras, pois com o vácuo aberto pode ocorrer a sucção de sujeira do ambiente para dentro do sistema. Quando as teteiras começarem a ser acopladas deve-se abriu o vácuo para que ocorra o encaixe correto e se inicie a sucção (ROSA et al, 2009).

Após o término por completo da descida do leite o vácuo deve ser deligado e as teteiras devem ser desacopladas imediatamente dos tetos. Manter a sucção com o úbere vazio pode ocasionar lesões no esfíncter mamário, causando danos irreversíveis no canal de descida do leite. Estes danos favorecem o aparecimento de mastites e também deixam uma porta aberta para microrganismos adentrarem no úbere (ROSA et al, 2009). 


\subsection{MANEJO DE BOAS PRÁTICAS NO PÓS ORDENHA}

O pós-dipping é o procedimento que deve ser realizado após a retirada das teteiras a partir da imersão dos tetos em solução antisséptica iodada e glicerinada logo após a ordenha. O iodo tem uma função bactericida, enquanto a glicerina tem a função de hidratar e de selar o esfíncter da vaca, barrando a entrada de microrganismos para dentro do úbere (BELOTI, 2008).

É interessante que logo após a ordenha as vacas sejam mantidas de pé, pois assim evita que as mesmas deitem e sujem os tetos que estão com a solução de pós-dipping e o esfíncter ainda semiaberto, evitando a entrada de microrganismos e sujidades no canal mamário. Uma das táticas para manter as vacas de pé é fornecer alimentação em cochos logo após a ordenha (BELOTI, 2008).

Após a saída dos animais deve-se realizar a limpeza de toda a sala e do sistema de ordenha. A sala de ordenha deve ser lavada com água corrente e todos os equipamentos utilizados devem ser lavados com água e detergente (ROSA et al, 2009).

Os sistema de ordenha, tanto canalizado como balde ao pé deve passar por um sistema específico de limpeza, com a associação de produtos químicos tanto para retira os resíduos orgânicos como os inorgânicos.

O primeiro passo é realizar um pré-enxágue no sistema com água morna na temperatura de $40^{\circ} \mathrm{C}$. a intenção desta lavagem é conseguir arrastar até $97 \%$ dos resíduos de leite que se encontram no equipamento (EMBRAPA, 2010).

Após o pré-enxague deve-se realizar a lavagem do sistema com um detergente alcalino clorado diluído em água conforme a indicação do fabricante, com uma temperatura de $77^{\circ} \mathrm{C}$. Esta fase deve ter uma duração de 10 minutos de circulação, o intuito é uma assepsia do equipamento e a remoção total de componentes orgânicos do leite no sistema (EMBRAPA, 2010). 
Após o uso do detergente alcalino vem a terceira e última fase, que é a limpeza do sistema com um detergente ácido. O detergente ácido deve ser utilizado uma vez por semana com circulação de 10 minutos, com o intuito de retirar os minerais do leite que depositam-se na ordenhadeira. Logo após a passagem deste produto deve-se realizar a circulação de água limpa para retirar totalmente o detergente do sistema (EMBRAPA, 2010).

Sempre deve ser lembrado que mesmo com os procedimentos de limpeza e a sanitização realizados após cada ordenha do dia, no próximo dia mesmo com o sistema limpo deve-se realizar a sanitização do sistema com produtos a base de hipoclorito de sódio diluído em água a temperatura ambiente e após esse procedimento o enxágue com água morna. Este manejo tem a finalidade de retira por completo qualquer tipo de material que tenha restado no sistema da limpeza anterior (EMBRAPA, 2010).

\subsection{MASTITE E A RELAÇÃO COM CCS E DIMINUIÇÃO NA QUALIDADE DO LEITE CRU E SUBPRODUTOS}

A mastite bovina é a doença mais comum que afeta os rebanhos leiteiros do mundo inteiro, tem a capacidade de causar sérios prejuízos econômicos tanto ao produtor de leite quanto à indústria de laticínios (TOZZETTI et al 2008).

Leite de animais acometidos por mastite promovem grandes mudanças na composição do leite (redução de cálcio, fósforo, proteína e gordura, e aumento em sódio e cloro) reduzindo a qualidade do produto. Além disso, os antibióticos utilizados para tratar esta enfermidade são de grande importância para a indústria e a saúde pública (TOZZETTI et al, 2008).

A mastite é caracterizada por uma inflamação na glândula mamária, e é uma consequência da interação de fatores relacionados ao animal, patógeno e ambiente (BRITO \& BRITO, 2000). Em torno de $90 \%$ das mastites são causadas por bactérias, mas, além disso, fungos, leveduras, algas e vírus também podem estar envolvidos na etiologia da doença, porém a ocorrência é baixa (PHILPOT \& NICKERSON 1991). 
A mastite pode ser dividida em dois grupos, a clínica apresenta sinais de edema, hipertermia, inchaço e dor na glândula mamária e o maior sinal é apresentar grumos, pus ou alterações nas características do leite. A subclínica não mostra sinais evidentes, mas causa diminuição nos sólidos totais do leite e um aumento na Contagem de Células Somáticas (CCS).

As Células Somáticas são células encontradas no leite e provém das células sanguíneas brancas do animal, que entram no leite através de uma resposta a invasão bacteriana no úbere (TOZZETTI et al 2008).

Para diminuir os quadros de mastite e consequentemente a quantidade de células somáticas no leite recomenda-se utilizar um manejo de boas práticas de ordenha. Segundo TOZZETTI et al (2008) algumas práticas devem sempre ser lembradas:

- Correta higienização de equipamentos;

- Higienização dos tetos dos animais;

- Descartar vacas com problemas de mastite crônica;

- Ordenhar vacas infectadas por último;

- Monitoramento do estado de saúde;

- Uso correto de antibióticos (respeitar o tempo de carência);

- Realizar os testes de caneca de fundo preto e o CMT.

A ocorrência de mastite nas vacas aumenta de forma significativa a quantidade de CCS no leite. Além disso pode gerar perdas financeiras para o produtor, pois o mesmo recebe pela qualidade do leite e não só por quantidade, gera também perdas para a indústria interferindo na qualidade dos produtos lácteos.

O leite de vacas acometidas com mastite tem uma diminuição significativa de caseína do leite, reduzindo em até $11 \%$ o rendimento na produção de queijos. Além disso, pode ocasionar aumento da umidade nos queijos e diminuição do tempo de prateleira do produto (SANTO, 2011). De acordo com SANTOS (2011) outros prejuízos também podem ser observados:

- Alteração na estabilidade do leite em pó, diminuindo o tempo de prateleira; 
- Diminuição na qualidade sensorial da manteiga;

- Inibição dos microrganismos de fermentação do leite para a produção de iogurte;

- Existe uma relação entre aumento de CCS e resíduo de antibiótico no leite, tornando-se um perigo para a população consumidora.

\subsection{CBT E A RELAÇÃO COM A PERDA DA QUALIDADE DO LEITE E SEUS SUBPRODUTOS}

Como o próprio nome sugere CBT é a contagem do número de colônias bacterianas presentes em uma amostra de leite previamente incubada a uma temperatura de $32^{\circ} \mathrm{C}$ durante 48h (SANTOS, 2007).

A CBT fornece os dados da quantidade de bactérias que existem no leite, sendo um grande indicativo para determinar a qualidade higiênica do leite. Estes dados estão profundamente relacionados com falhas nos manejos de boas práticas de ordenha que podem ocasionar problemas na qualidade higiênica do leite (SANTOS, 2007).

Segundo CASTRO et al (2014) O problema da qualidade microbiológica do leite cru no Brasil é bem mais acentuada que em outros países, devido ao fato de que o leite que segue para as indústrias de beneficiamento provém de inúmeras pequenas propriedades rurais, diferente do que ocorre na Europa e nos Estados Unidos, de onde o leite provém de poucas e grandes propriedades.

O leite que apresenta baixa qualidade higiênica e consequentemente alta contagem bacteriana é um sério gargalo na produção de derivados, pois quando o leite apresenta qualidade microbiológica baixa $\mathrm{o}$ produto gera menor rendimento na indústria e impossibilita a produção de derivados nobres (CASTRO et al, 2014).

Ao contrário disso, um leite com boa qualidade microbiológica aumenta o rendimento e a capacidade da produção de derivados nobres, gerando maior lucratividade para a indústria e para o produtor, já que o produtor também ganha referente a qualidade do leite produzido e não somente pela quantidade (JUNIOR et al, 2014). 
Em um estudo realizado por JUNIOR et al (2014) ao analisar 92 propriedades leiteiras na região norte central do estado do Paraná, constatou que as propriedades que adotaram o manejo de boas práticas de ordenha produzem leite cru refrigerado com qualidade internacional.

Melhorar a qualidade microbiológica do leite é possível independente do tamanho da propriedade, basta seguir os manejos de boas práticas na ordenha. Além de produzir um alimento de maior qualidade, o produtor tem a possibilidade de melhorar a sua renda, devido ao leite com qualidade higiênica superior ter maior valor ao litro produzido.

De acordo com CASSOLI (2013) leite com CBT elevada tem o risco de precipitação da caseína por ação das enzimas produzidas pelas bactérias antes do processo térmico, reduzindo o tempo de prateleira do produto.

Existem alguns cuidados que devem ser tomados pelos produtores para que ocorra a redução na CBT do leite, sendo os seguintes:

- Realizar pré e pós dipping;

- Correta sanitização de todos os equipamentos utilizados na ordenha;

- Perder manias e vícios que durante o processo possam acarretar em contaminação do leite;

- Resfriar o leite a temperatura de $4^{\circ} \mathrm{C}$ em no máximo 3 horas após a ordenha para que não ocorra multiplicação microbiana em massa.

\subsection{INSTRUÇÃO NORMATIVA № 62 DE 29 DE DEZEMBRO DE 2011}

A IN 62 que tem por finalidade substituir a IN 51 de 18 de Dezembro de 2002 tem o papel de regulamentar à produção, identidade e qualidade do leite tipo A. Esta instrução é aplicável somente ao leite de vaca (BRASIL, 2011).

Os Quadros a seguir trazem as informações principais referentes as instalações do sistema de ordenha, manejo e parâmetros de qualidade segundo a IN 62 para que se obtenha um leite de boa qualidade. 
Quadro 1. IN 62 sobre as instalações.

Estrutura coberta e acabada com material de boa qualidade e com piso de cimento.

Instalação de água com pressão para lavagem do local.

Forração do teto feita com material impermeável.

Possuir equipamentos de ordenha mecânica.

Controle de pragas nas instalações.

Fonte: Adaptado de BRASIL (2011)

Quadro 2. IN 62 Sobre o manejo com os animais.

Prévia lavagem dos tetos, pré-dipping e secagem.

Descarte dos primeiros jatos e testes de mastite.

Realizar um pós-dipping com produtos adequados.

Manter os animais em pé por $\mathbf{3 0}$ minutos após a ordenha.

O ordenhador deve manter sempre as mãos limpas e higienizadas.

Todo o equipamento após a ordenha deve ser lavado e higienizado com detergente alcalino todos os dias e com detergente ácido apenas uma vez por semana.

Fonte: Adaptado de BRASIL (2011)

Quadro 3. IN 62 Sobre os principais níveis de qualidade do leite.

\section{CBT Máx 100 UFC \\ CCS Máx 400 CCS}

Ausência total de resíduos de antibióticos

Ausência de água no leite

Fonte: Adaptado de BRASIL (2011) 
Além dos níveis demonstrarem para o produtor como está a situação do leite produzido na fazenda e a qualidade sanitária do produto e do rebanho ordenhado, estes resultados também são uma fonte de aumento de renda na propriedade, tudo devido ao fato de que a maioria dos laticínios paga e penaliza o leite cru por qualidade e não somente por quantidade. Desta forma os produtores que encontram-se produzindo dentro dos padrões podem desfrutar de um maior rendimento mensal quando comparado aos que se encontram longe dos padrões de qualidade.

\section{CONSIDERAÇÕES FINAIS}

Considerando o cenário de produção de leite no Brasil, o nosso país é uma grande potência mundial para a produção de leite. Tudo isso devido à facilidade da implantação através das grandes extensões de terras e o clima favorável para a criação de bovinos. Mesmo assim o produtor Brasileiro ainda tem uma visão da bovinocultura como um segundo plano no meio agropecuário, deixando as boas práticas de lado e diminuindo a qualidade do produto.

O produtor deve tecnificar cada vez mais a sua produção de leite, buscando melhorar cada vez mais a sua forma de produção, diminuindo assim os prejuízos causados na indústria e aumentando o recolhimento financeiro a parti do leite, tudo graças às indústrias adotarem um pagamento por qualidade do leite cru refrigerado.

\section{REFERÊNCIAS}

BELOTI, V.; FAGNANI, R.; BATTAGLINI, P.P.A.; TAMANINI, R.; DA ANGELA, R.L. Boas práticas na ordenha. Universidade Estadual de Londrina - UEL/Lipoa 2008.

BRASIL. Ministério da Agricultura Pecuária e Abastecimento. INSTRUÇÃO NORMATIVA № 62, DE 29 DE DEZEMBRO DE 2011.

BRITO, J.R.F; BRITO, M. A.V.P. Mastite bovina. São Paulo: Manole, p. 114- 129. 2000. 
BRITO, M.A.V.P. et al. Identificação de contaminantes bacterianos no leite cru de tanques de refrigeração. Revista do Instituto de Laticínios Cândido Tostes, v. 57, n. 327, p. 83-88, 2002.

CARVALHO, S.T.; SILVA, P.A.M.; BRASIL, B.R.; CABRAL, F.J.; GARCIA, C.J.; OLIVEIRA, N.A. Qualidade do leite cru refrigerado obtido através de ordenha manual e mecânica. Rev. Inst. Latic. "Cândido Tostes", Jan/Fev, n 390, 68:05-11, 2013.

CASSOLI, D.L. O que acontece com a qualidade do leite até chegar a indústria e ser processado?. Acesso em: 23/01/2018. Disponível em: $<$ https://www.milkpoint.com.br/colunas/clinica-do-leite/o-que-acontece-com-aqualidade-do-leite-ate-chegar-a-industria-e-ser-processado-205293n.aspx> . Agosto de 2013.

CASTRO, K. A. et al. Efeito da contagem de células somáticas sobre a qualidade dos queijos prato e mussarela. Revista Brasileira de Tecnologia Agroindustrial, v. 8, n. 1, p. 1237-1250, 2014.

ECKSTEIN, I.I.; POZZA, S.S.M.; ZAMBOM, A.M.; RAMOS, O.C.E.C.; TSUTSUMI, Y.C.; FERNANDES, T.; ECKSTEIN, I.E.; BUSANELLO, M. Qualidade do leite e sua correlação com técnicas de manejo de ordenha. Mal. Cdo. Randon., v.13, n.2, abr/jun. p.143-151, 2014.

EMBRAPA. Limpeza dos utensílios e dos equipamentos de ordenha. Acesso: 07/01/2018. Disponível em: <http://www.cnpgl.embrapa.br/sistemaproducao/473142limpeza-dos-utens\%C3\%ADlios-e-equipamento-de-ordenha> . Outubro de 2010.

EMBRAPA. Ordenha manual e mecânica. Acesso: 04/01/2018. Disponível em: <http://www.cnpgl.embrapa.br/sistemaproducao/47312-ordenha-manual-emec\%C3\%A2nica> . Janeiro de 2008. 
IBGE - INSTITUTO BRASILEIRO DE GEOGRAFIA E ESTATÍSTICA. Indicadores IBGE - Estatística da Produção Pecuária. CEPAGRO - Comissão Especial De Planejamento, Controle E Avaliação Das Estatísticas Agropecuárias. Março de 2015.

IBGE. Instituto Brasileiro de Geografia e Estatística. Produção da pecuária municipal. Volume 39, Brasil - 2011.

JUNIOR, R.C.J.; SHCAIRA, L.C.; SILVA, F.F.; PARREN, E.G. BELOTI, V. Influência de boas práticas de higiene de ordenha na qualidade microbiológica do leite cru refrigerado. Rev. Inst. Laticínios Cândido Tostes, Juiz de Fora, v. 69, n. 6, p. 395404, nov/dez, 2014.

LANGONI H.; SAKIYAMA, D.T.P.; GUIMARÃES, F. de F. et al. Contagem de células somáticas e de microrganismos mesófilos aeróbios em leite cru orgânico produzido em Botucatu (SP). Veterinária e Zootecnia, v.18, n.4, p.653-660, 2011.

MAIA, S.B.B.; PINTO, R.A.; MARQUES, T.Y.C.; ROITMAN, B.F.; LYRA, D.D. Produção de leite no Brasil - BNDES. Ministério do Desenvolvimento, Indústria e Comércio Exterior. BNDES Setorial 37, p. 371-398. 2010.

MARASSATTO, M.C. Boas práticas na ordenha de bovinos. Acesso: 05/01/2018. Disponível em: <http://www.esalq.usp.br/cprural/boapratica/mostra/100/boaspraticas-na-ordenha-de-bovinos.html> . Maio de 2014.

MORINI, R.M. Qualidade do leite e manejo de ordenha. Monografia (Graduação) Universidade Federal de Goiás, Campus Jataí. 2009.

NETTO, S.G.F.; BRITTO, G.L.; FIGUEIRÓ, R.R. A ordenha da vaca leiteira. Comunicado técnico da EMBRAPA. RO, Porto Velho, Novembro de 2006.

OLIVEIRA, C.R. Boas práticas agropecuárias na ordenha. Universidade Estadual de Goiás - UEG. São Luís de Montes Belos, Agosto de 2015.

PHILPOT, W.N.; NICKERSN, S.C. Mastitis: Counter Attack. Naperville: Babson Bros, 150p. 1991. 
ROSA, S.M. COSTA, P.R.J.M.; SANT'ANA, C.A.; MADUREIRA, P.A. Boas práticas de manejo - ORDENHA. UNESP, Campus Jaboticabal. Funep, 2009.

SANTOS, M.V. Boas práticas de produção associadas à higiene de ordenha e qualidade o leite. O Brasil e a nova era do mercado do leite - Compreender para competir. 1 ed. Piracicaba - SP: Agripoint Ltda, v.1, p. 135-154. 2007.

SANTOS, M.V.; FONSECA, L.F.L. Estratégias para controle de mastite e melhoria da qualidade do leite. Barueri: Manole, 2007. 314 p.

SANTOS, V.M. Perdas para o produtor e para a indústria. Acesso: 12/01/2018. Disponível em: <http://qualileite.org/pdf/Artigos-tecnicos-publicados-em-revista-dedivulgacao/Inforleite/2011/1.pdf> . 2011.

SILVA, R.W.S.M.; PORTELLA, J.S.; VERAS, M.M. Circular técnica 27: Manejo Correto de Ordenha e Qualidade do Leite. In: MINISTÉRIO DA AGRICULTURA PECUÁRIA E ABASTECIMENTO - MAPA, 2002.

TOZZETTI, D.S.; BATAIER, M.B.N.; ALMEIDA, L.R. Prevenção, controle e tratamento das mastites bovinas - Revisão da Literatura. Revista Científica Eletrônica de Medicina Veterinária. Ano VI, Número 10, Janeiro de 2008.

ZAFALON, F.L.; POZZI, R.C.; CAMPOS, P.F.; ARCARO, P.R.J.; SARMENTO, P.; MATARAZZO, V.S. Boas práticas de ordenha. São Carlos - SP: Embrapa Pecuária Sudeste, 2008.

ZOCCAL, A. Alguns números do leite. Revista Balde Branco. Acesso: 02/01/2018. Disponível em: <http://www.baldebranco.com.br/alguns-numeros-do-leite/>.

Enviado: Agosto, 2018.

Aprovado: Julho, 2019. 